\title{
Factors Influencing Elementary Teachers' Readiness in Delivering Sex Education amidst Covid-19 pandemic
}

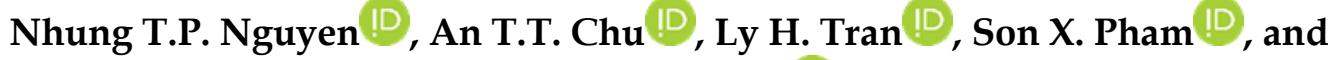 \\ Hien N. Nguyen \\ Vinh University, Nghe An, Vietnam \\ Vinh T. Nguyen* ${ }^{*}$ \\ FPT University, Hanoi, Vietnam
}

\begin{abstract}
The emergence of variants of Covid-19, the persistence of lockdowns in many countries, and the necessity to maintain sustainable education have resulted in a shift from the traditional classroom to virtual space. As such, there is a strong need to leverage technological advances while mitigating the challenges faced by primary teachers. Through the incorporation of eight elements, the authors sought to better understand factors that influence teacher readiness to deliver sex education in primary schools. Structural Equation Modeling was employed to assess the proposed conceptual model. The online survey was designed and distributed by Google Forms. Based on the results from 383 individuals, the findings revealed that facilitating conditions, educational policy, and parental involvement all had a relationship with teacher readiness. Digital content positively influenced performance expectancy and effort expectancy. Sexual knowledge had a statistically significant and positive influence on effort expectancy. Finally, openness had a statistically significant and positive influence on performance expectancy. The significant exceptions were that effort expectancy was not found to predict teacher readiness, and performance expectancy was not found to influence teacher readiness. The reasons for these non-significant correlations were briefly discussed and more studies on this topic are called to investigate these unexpected outcomes in more detail. The level of readiness, as well as theoretical and practical implications for scholars and practitioners, were discussed.
\end{abstract}

Keywords: sex education; teacher readiness; primary schools; educational policy; parental involvement

\footnotetext{
${ }^{*}$ Corresponding author: Vinh T. Nguyen, vinhnt56@fe.edu.vn
} 


\section{Introduction}

The outbreak of the Covid-19 pandemic and the emergence of its variants have had a profound effect on every aspect of life on a global scale, from travel, retail, restaurants, aviation to higher and primary education (Pokhrel \& Chhetri, 2021; Tadesse \& Muluye, 2020). Organizations and businesses must be able to adapt quickly to the change in the "new normal" conditions. As a result, ideas have been formulated, solutions have been proposed to maintain daily activities, of which remote working via digital tools is one of the most widely used ones today (Gallegos et al., 2020; Shareefa et al., 2021). Although remote working has been discussed for a long time, it was only when Covid-19 had its debut that this type of working became more popular (Gallegos et al., 2020). In reality, although many benefits are expected to originate from working remotely, numerous challenges must be addressed, such as infrastructure, new policies suitable for remote working, integration, new content, assistive devices, usability, implementation, etc. (Gocotano et al., 2021; Wenceslao \& Felisa, 2021).

Organizations and enterprises are taking several urgent steps to support remote working, such as acquiring equipment, launching information technology training courses, digitizing documents, and the education sector is not immune to this trend (Gallegos et al., 2020; Shareefa et al., 2021). Many lectures have been digitized, and lessons have also been videotaped for online education. These activities appear straightforward at first glance, but they are fraught with difficulties, such as needing to record a lecture many times, digitally converting information with dynamic features or time, Internet connection issues, storage capacity, and so forth (Gocotano et al., 2021). In addition, insufficient battery life, teacher's lack of engagement with the students, class disruption, zoomed-out videos, unclear slides, videos, and difficulty to open large files are problems students face (Gocotano et al., 2021). The aforementioned issues are tough for university professors, but they are much more difficult for primary school teachers (Iivari et al., 2020; Zakharov et al., 2021), especially when it comes to courses that are cognitively and psychologically inclined, such as sex education (or SexEd) (Goldfarb \& Lieberman, 2021). Sex education plays an important role in the development of children (Jin, 2021). To begin with, sex education is critical to the whole development of a child's personality. Second, it complies with the rules of teenage psychological and physiological growth. Strong understandings and influences of love activities and sex life in society, together with sexual vibes, gender changes in the body, and emotions, gradually build in children a new type of knowledge that was not learned in school or at home (Cacciatore et al., 2019). Third, providing children with sex education will help them grasp the reproductive issues and know how to restrict fertility, particularly broad views and conceptions regarding population difficulties (Warzecha et al., 2019). The required information about sex life will help them be more vigilant, stronger, and aware of how to avoid societal problems, therefore contributing to the creation of a sustainable society (Berglas et al., 2016).

The need to transition primary school pupils to an online learning environment has prompted numerous concerns, particularly about digital security (Plaza-delPino et al., 2021; Russell et al., 2020). Children are routinely exposed to digital 
devices, which exposes them to screen pornography, most of it is misogynistic and inappropriate for their age (Plaza-del-Pino et al., 2021). In some regions, parents and teachers are not adequately trained with information technology skills to mitigate the hazards (Bartau-Rojas et al., 2018). As a result, it is critical to include parents, teachers, and relevant authorities in developing suitable policies, solutions, technology, and procedures to safeguard children against abuse (Russell et al., 2020; Schneider \& Hirsch, 2020). Furthermore, the usage of appropriate terminology in the network environment is an issue that must be addressed. For example, when the sex content is conveyed indirectly or impliedly, especially for young pupils, the message can be more confusing and harder to understand (Shin et al., 2019). It might be difficult to use straightforward terms in sex education due to software content filtering (e.g., automatic mute when encountering sensitive keywords or pictures). This is a painful issue that is frequently highlighted in the media, but it also barely reaches the level of "awareness" (Choi, 2013; Voyiatzaki et al., 2021). In developing countries, sex education is a contentious issue in both public health and education policy (Leung et al., 2019). Thus, teachers should be leaders in the education and training of the country's future generations. Only when teachers carry out their duty effectively in today's demanding environment will students be prepared with the required information, abilities, and attitudes concerning psychophysiology, allowing them to develop to their full potential (Jørgensen et al., 2019; Lameiras-Fernández et al., 2021; Plaza-del-Pino et al., 2021).

Numerous scientific papers have been published regarding online training in the context of the Covid-19 epidemic (Alea et al., 2020; Alghamdi \& Al-Ghamdi, 2021; Bautista Jr et al., 2021; Funa \& Talaue, 2021; Shareefa et al., 2021), but the most of them are about the university setting, with only a handful devoted to general education (Alghamdi \& Al-Ghamdi, 2021). The paucity is more visible in primary education, particularly in sex education for children (Choi, 2013; Espinosa \& Barraza, 2021; Schneider \& Hirsch, 2020). Several authors have proposed a sex competence framework for schools, but they have not taken into account teachers' preparation for this competency framework in the context of the Covid-19 epidemic (Initiative, 2020; Wang \& Hall, 2018). As a result, the goal of this research is to understand the factors influencing primary school teachers' readiness to provide children with SexEd. Researchers may utilize these findings to improve or integrate existing models, and principals and policymakers can use them to develop policies and solutions for creating a sustainable learning environment for children.

\section{Literature Review and Theoretical Framework}

The topic of sexual education has elicited interest among academics of all levels (Kim et al., 2021; Plaza-del-Pino et al., 2021). Kim et al. (2021) investigated gender disparities in sexual behavior among 2460 high school students who reported having had sexual experiences. In the study, the researchers found that boys had earlier sexual debuts, used contraceptives less frequently, and received fewer sex education lessons in schools. Lameiras-Fernández et al. (2021) provided an overview of what is known regarding the diffusion and efficacy of sex education programs to influence better public policy decisions. The authors observed that 
while assessments of digital platforms and blended learning indicate better efficacy in terms of promoting sexual and reproductive health in teenagers, they also entail increasing risks of bias. In the authors' view, determining the success of sexual education programs requires a more rigorous assessment, given the potential of new technology, which may lead to more cost-effective treatments than traditional programs. On the topic of SexEd in the classroom, Plaza-del-Pino et al. (2021) examined the perspectives of 15 primary school teachers. From the analysis, the authors identified two key themes, which are the lack of training to fears of the families. Hamilton-Giachritsis et al. (2021) explored how experts who assist with victims interpret internet child sexual assault. According to the findings, there is frequently a low knowledge of the hazards and severity of technology-assisted online child sexual abuse, which can lead to victims continuing at risk, a systemic failure to protect, and a decreased probability of obtaining effective therapies. Martin et al. (2020) showed that the implementation of the sex education program for preschool teachers led to improved knowledge and attitudes. The aforementioned studies demonstrate that while SexEd has been captured from different points of view, a gap exists in determining factors that influence teachers' readiness to disseminate SexEd in primary schools amidst the covid-19 pandemic. Thus, the current study contributes to the body of knowledge by investigating the effects of relationship amongst factors toward teachers' readiness in primary schools. For elementary teachers to be successful with remote teaching, it is necessary to identify the dimensions of readiness they should possess for SexEd in the virtual space.

The concept of readiness for online learning can be attributed to Warner et al. (1998). Online readiness was characterized by Borotis and Poulymenakou (2004) as being mentally and physically prepared for certain online learning experiences and activities. For this study, teacher readiness is defined as the degree to which an individual feels confident about oneself in disseminating SexEd in primary schools. Three questions were used to assess teacher readiness including 1) I feel that I am ready to teach SexEd for children, 2) I feel confident that I can mentor my students, 3) I think that I can organize my classes online efficiently.

Many researchers have attempted to assess readiness factors that influence online learning performance by either confirming an existing model or expanding it with additional components (Dorsah, 2021; Zou et al., 2021). For example, Hung (2016) identified four teachers-as-learners' factors, including communication selfefficacy, institutional support, self-directed learning, and learning-transfer selfefficacy. Zou et al. (2021) considered other factors such as technology access and computer self-efficacy. Sailer et al. (2021) suggested that the facilitating conditions provided by higher education institutions influence the context of teaching and learning significantly. Churiyah et al. (2020) highlighted that education policy plays an important role to conduct learning from home for kids as many parents strongly support this policy because of the spread of the coronavirus. Several authors studied in detail parental engagement factors in online learning environments (Fauzi \& Khusuma, 2020; Stevens \& Borup, 2015), and they suggested that teachers and parents should coordinate to improve student engagement. Due to the involvement of technological aspects in online 
teaching/learning, a majority of recent research integrated the Unified Theory of Acceptance and Use of Technology (UTAUT) model to evaluate online learning performance (Hu et al., 2020; Mittal et al., 2021). UTAUT has been proven to be an effective model in the context of mobile technology learning for students and academics at university levels (Omar et al., 2019). However, there is little data with elementary or secondary school teachers (Adov et al., 2017). In another line of research, Patra et al. (2021) emphasized that teachers should develop learnercentric digital content to accommodate students' needs. Their recommendation was aligned with the challenges posed previously. On the topic of SexEd, Westwood and Mullan (2007) reported that teachers lack sufficient sexual health expert knowledge to contribute to current guidelines for SexEd in secondary schools. In addition, the literature in the field recounts various creative programs that fail to owe to elementary school teachers' reluctance to openly and firmly confront the sexuality topic (Pellejero Goni \& Torres Iglesias, 2011). The following dimensions were drawn to assess teacher readiness for online SexEd based on the selective reviews above: digital contents, sexual knowledge, openness, facilitating conditions, effort expectancy, performance expectancy, educational policy, and parental engagement.

Facilitating Condition: Facilitating Condition is defined as a person's perception of whether there is an organizational and technological environment to support the utilization of a system (Venkatesh et al., 2003). This study employed four questions to measure facilitating conditions, including the following: 1) I have the devices/tools/apps necessary to teach SexEd online, 2) I am familiar enough with the devices/tools/apps to utilize them, 3) The devices/tools/apps are working properly, and 4) The service provider can assist me if I am having trouble using the devices, tools, or apps. Thus, the hypothesis below was proposed:

Hypothesis 1 (H1). Facilitating Conditions positively influence Teacher Readiness on teaching SexEd in primary schools.

Effort Expectancy: UTAUT defines Effort Expectancy as the ease with which a system can be used, and this is a key prediction of the model (Venkatesh et al., 2003). This factor has been justified in a variety of settings, particularly in blended learning (Azizi et al., 2020). In the context of this study, effort expectancy refers to users' perceptions of how easy an online learning environment allows the primary teacher to deliver SexEd. The effort expectancy was assessed using the following four questions: 1) I would find the online learning environment (e.g., devices/tools/apps) easy to use, 2) It would not take me long to figure out how to use devices/tools/apps for teaching kids, 3) I will be able to interact with devices, tools, and apps clearly and understandably, and 4) Being skilled at using devices/tools/apps is an easy task for me. Thus, the hypothesis below was proposed:

Hypothesis 2 (H2). Effort Expectancy positively affects Teacher Readiness on teaching SexEd in primary schools.

Performance Expectancy: The term "Performance Expectancy" refers to a person's perception that he or she will be able to achieve their work performance goals by employing the system (Venkatesh et al., 2003). In the context of this study, 
performance expectancy refers to the primary teachers' belief that using devices/tools/apps is helpful for delivering SexEd. Three questions were used to estimate performance expectation: 1) I would find the devices/tools/apps useful for teaching SexEd, 2) I think using devices/tools/apps will help me deliver contents that I want my students to learn, 3) I think using devices/tools/apps will help me improve ways of teaching. Thus, the following hypothesis was proposed: Hypothesis 3 (H3). Performance Expectancy positively affects Teacher Readiness on teaching SexEd in primary schools.

Educational policy: Educational policies are governed by 'quality' education paradigms, in which quality is defined as economic metrics such as effectiveness, efficiency, economy, and accountability, as well as academic achievement (Steiner, 2012). For this study, the educational policy relates to the primary teachers` belief that having a clear guideline for teaching SexEd will help them feel more confident. Three questions were used to measure educational policy guidelines. 1) I was provided with necessary guidelines/policies from schools and states that help me carry my class online easily, 2) The guidelines/policies are understandable and easy to follow, 3) It is not difficult for me to follow the guidelines/policies while delivering class lessons. The following hypothesis was proposed:

Hypothesis 4 (H4). Educational policy positively affects Teacher Readiness on teaching SexEd in primary schools.

Parental Involvement: It has been shown that parental involvement through good parenting at home has a significant impact on children's achievement and adjustment even after all other factors have been eliminated (Desforges \& Abouchaar, 2003). Parental involvement was emphasized in the context of digital sexual education (Aventin et al., 2020) where the authors suggested that efforts must be devoted to increasing the confidence of school personnel and teachers to communicate with parents on sensitive topics while simultaneously focusing on parental components. In this study, parental involvement factor was measured by using three questions: 1) I can contact students' parents whenever it is needed while teaching SexEd online, 2) Students` parents are accessible at any time while the class is running, 3) Students parents are presented to help kids focus on learning. The hypothesis below was proposed:

Hypothesis 5 (H5). Parental Involvement positively affects Teacher Readiness for teaching SexEd in primary schools.

Digital contents: It is not easy to develop a good digital learning media since it requires not only pedagogy knowledge, but technology knowledge and coding skills as well (Fiangga et al., 2021). This is a challenging issue for a vast number of non-technical teachers (Ferri et al., 2020). In the context of this study, digital contents refer to materials that teachers use and deliver to kids via an online communication channel. Three questions were used to measure the extent to which digital contents are available to be used by primary teachers/students in SexEd: 1) I have digital materials for SexEd, 2) Digital materials are appropriate for kids, 3) Digital materials are easy to operate and delivered via online learning environment. It is argued that the greater the availability of digital content, the 
lesser the effort and the higher the performance required by teachers, thus the following hypotheses were proposed:

Hypothesis 6 (H6). The availability of digital content has a positive effect on Performance Expectancy for primary teachers.

Hypothesis 7 (H7). The availability of digital content has a positive effect on Effort Expectancy for primary teachers.

SexEd Knowledge. The knowledge factor has been explored to measure teacher preparation for online teaching (Pellejero Goni \& Torres Iglesias, 2011; Westwood $\&$ Mullan, 2007). Knowledge in the context of this study refers to a comprehension of SexEd. Three questions were used to estimate primary teachers` knowledge: 1) I feel confident when delivering SexEd, 2) I can look at SexEd from different points of view, 3) I can justify SexEd in different settings. If teachers have more knowledge, they should make fewer efforts. Thus, the following hypothesis was proposed:

Hypothesis 8 (H8). SexEd Knowledge has a positive effect on Effort Expectancy for primary teachers.

SexEd Openness: As part of openness, teachers needed to be willing to answer questions without focusing on the topic (Booth-Butterfield \& Sidelinger, 1998); maintain an open-minded attitude; balance openness with privacy; and take into account the characteristics of their students (Kirkman et al., 2005). Some studies (Pellejero Goni \& Torres Iglesias, 2011; Plaza-del-Pino et al., 2021) pointed out that teachers of primary schools are often reluctant to speak openly about sexuality. Three questions were employed to measure Openness, which are as follows: 1 ) I'm open-minded to sensitive topics, 2) I am willing to discuss sexual content with others, and 3) I talk with kids considering their emotions and behaviors. If teachers have been open to their students, they should have high performance. Thus, the following hypothesis was proposed:

Hypothesis 9 (H9): SexEd Openness has a positive effect on Performance Expectancy for primary teachers.

These assumptions guided the development of the study model illustrated in Figure 1. The ellipses represent constructs (also known as latent variables) evaluated by a series of items, and the arrows represent hypotheses numbered 1 to 9. 


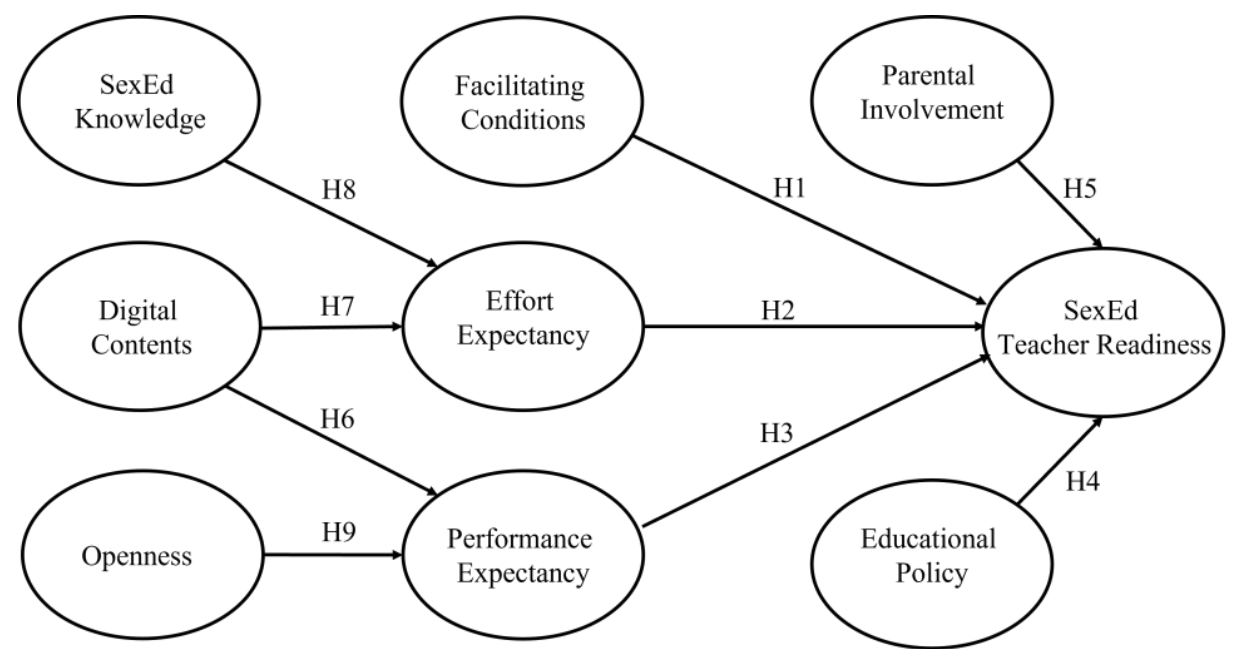

Figure 1. The proposed theoretical model with hypotheses from H1 to H9

\section{Methodology}

\subsection{Participants and Data Gathering Tools}

Nonprobability, purposive sampling was used to collect study data in order to overcome the problem of being unable to identify the members of the population individually (Stratton, 2021). The online survey was developed using Google Forms and distributed via online channels. A Google Form with an invitation message was shared via emails and social media channels (such as Facebook, Twitter). The interest group is made up of primary school SexEd teachers in the north, middle, and south of Vietnam. Those who participated in the survey were recruited on an opt-in basis, and they can opt out at any time. Through the authors' community, the snowball sampling technique is expected to reach 700 users. The survey consists of 4 questions to gather participants' demographic information, and 29 Likert-type questions to examine various points of view teaching SexEd in primary schools during the covid-19. There was no specific personal information revealed in this investigation, so no ethical approval was required.

Kock and Hadaya (2018) suggested a tool (Soper, 2016) to estimate the appropriate sample size, and that tool was used to determine the sample size in this study. Using the tool, the following settings were adjusted: anticipated effect size (0.3), desired statistical power level (0.8), number of latent variables (9), number of observed variables (29), probability level (0.05). Thus, the sample size for this study was 184 .

\subsection{Measures}

A review of the survey questions using the research methodologies led to the selection of 29 questions for the study (see Table 1). A five-point Likert scale ( $1=$ Strongly Disagree, 2 = Disagree, $3=$ Neutral, $4=$ Agree, 5 = Strongly Agree) was used to measure teachers' readiness to teach SexEd in primary schools. 
Table 1. Construct and items

\section{Performance Expectancy \\ (PE1) I would find the devices/tools/apps useful for teaching SexEd. \\ (PE2) I think using devices/tools/apps will help me deliver contents that I want my students to know. \\ (PE3) I think using devices/tools/apps will help me improve my ways of teaching.}

\section{Effort Expectancy}

(EE1) I would find the online learning environment (e.g., devices/tools/apps) easy to use.

(EE2) It would not take me long to figure out how to use devices/tools/apps for teaching kids.

(EE3) I will be able to interact with devices, tools, and apps clearly and understandably.

(EE4) Being skilled at using devices/tools/apps is easy for me.

\section{Parental Involvement \\ (PI1) I can contact students ' parents whenever it is needed while teaching SexEd online. \\ (PI2) Students' parents are accessible at any time while the class is running. \\ (PI3) Students' parents are presented to help kids focus on learning.}

\section{Facilitating Conditions}

(FC1) I have the devices/tools/apps necessary to teach SexEd online.

(FC2) I am familiar enough with the devices/tools/apps to utilize them.

(FC3) The devices/tools/apps are working properly.

(FC4) The service provider can assist me if I am having trouble using the devices, tools, or apps.

\section{Educational Policy}

(EP1) I was provided necessary guidelines/policies from schools and states that help me carry my class online easily.

(EP2) The guidelines/policies are understandable and easy to follow.

(EP3) It is not difficult for me to follow the guidelines/policies while delivering class lessons.

\section{Digital contents}

(DC1) I have digital materials for SexEd.

(DC2) Digital materials are appropriate for kids.

(DC3) Digital materials are easy to operate and delivered via an online learning

environment.

\section{SexEd Knowledge}

(SK1) I feel confident when delivering SexEd.

(SK2) I can look at SexEd from different points of view.

(SK3) I can justify SexEd in different settings. We believe that teachers should make fewer efforts if they have more knowledge.

\section{SexEd Openness}

(OP1) I'm open-minded to sensitive topics.

(OP2) I am willing to discuss sexual content with others

(OP3) I talk with kids considering their emotions and behaviors.

\section{SexEd Teacher Readiness}

(TR1) I feel that I am ready to teach SexEd for children.

(TR2) I feel confident that I can mentor my students.

(TR3) I think that I can organize my classes online efficiently. 


\subsection{Data Analysis}

The proposed study model was evaluated using Generalized Structured Component Analysis (GSCA), a method that was chosen over Partial Least Squares Structural Equation Modeling (PLS-SEM) because it could be applied to small samples without having to assume rigid distributions (Hwang \& Takane, 2014). GSCA is a method for examining relationships between observed variables and latent variables by using components of observed variables as proxy variables. As an additional benefit to PLS-SEM, GSCA should have fewer assumptions regarding distributions (multivariate normality is not required for parameter estimation), unique component score estimates, and circumventing incorrect solutions in small samples. For hypothesis testing as well as supplementary investigations, GSCA Pro (Hwang et al., 2021) for generalized structural component analysis was employed (e.g., internal consistencies, correlations). This software allows users to view results and create models with ease using a graphical user interface.

\section{Results}

Inappropriate replies were eliminated during data collection (46 invalid answers due to picking just one option, 25 responses due to missing values). The total number of observations that remained in the study was 383 (accounted for $84.36 \%$ of 454 responses). The present study met the sample size requirements since its actual sample size was 383, exceeding the minimum suggesting criteria of 184 . Table 2 presents demographic information of respondents from the survey, with males accounting for $16.18 \%$, while females accounting for $83.82 \% .38 .38 \%$ of the respondents are under the age of $25,47.00 \%$ are between the ages of 26 and 35 , $10.7 \%$ are between the ages of 36 and 45 , and $3.92 \%$ are over 45 . In terms of years of experience, $4.44 \%$ have been in education for less than two years, $19.06 \%$ have been in education for five years, more than half of the respondents $(66.58 \%)$ have been in education for almost ten years, and $9.92 \%$ have more than ten years of experience. The vast majority of participants $(90.34 \%)$ stated that they work in public schools, whereas just a small percentage work in private institutions $(9.66 \%)$

Table 2. Demographic information about the participants

\begin{tabular}{|l|c|c|c|}
\hline \multicolumn{1}{|c|}{ Variable } & Item & Frequency & Percentage \\
\hline \multirow{4}{*}{ Gender } & Male & 62 & 16.48 \\
\hline \multirow{4}{*}{ Age } & Female & 321 & 83.82 \\
\cline { 2 - 4 } & $18-25$ & 147 & 38.38 \\
\cline { 2 - 4 } & $36-35$ & 180 & 47.00 \\
\cline { 2 - 4 } & $36-45$ & 41 & 10.70 \\
\cline { 2 - 4 } Year of Experience & Over 45 & 15 & 3.92 \\
\cline { 2 - 4 } & Less than 2 years & 17 & 4.44 \\
\cline { 2 - 4 } & $2-5$ years & 73 & 19.06 \\
\cline { 2 - 4 } & More than 10 years & 255 & 66.58 \\
\hline \multirow{2}{*}{ Working Sector } & Public schools & 38 & 9.92 \\
\cline { 2 - 4 } & Private schools & 376 & 90.34 \\
\hline \multicolumn{2}{|c|}{ Total } & 383 & 10.66 \\
\hline
\end{tabular}




\section{Quantitative Analysis}

Table 3 displays the descriptive data for each construct item. Means exceed the average point of 2.5, while standard deviations vary from 0.698 to 1.191 .

Table 3. Construct, Means and Standard Deviations of the indicators

\begin{tabular}{|c|c|c|c|}
\hline Construct & Item & Mean & SD \\
\hline \multirow{3}{*}{ Performance Expectancy } & PE1 & 4.230 & 0.814 \\
\hline & PE2 & 4.005 & 0.900 \\
\hline & PE3 & 3.684 & 1.105 \\
\hline \multirow{4}{*}{ Effort Expectancy } & EE1 & 4.052 & 0.889 \\
\hline & EE2 & 3.982 & 0.924 \\
\hline & EE3 & 4.117 & 0.784 \\
\hline & EE4 & 4.099 & 0.861 \\
\hline \multirow{3}{*}{ Educational Policy } & EP1 & 3.843 & 0.984 \\
\hline & EP2 & 3.807 & 0.956 \\
\hline & EP3 & 3.948 & 0.892 \\
\hline \multirow{4}{*}{ Facilitating Conditions } & FC1 & 3.867 & 0.991 \\
\hline & FC2 & 3.979 & 0.830 \\
\hline & FC3 & 3.159 & 1.121 \\
\hline & FC4 & 3.958 & 0.927 \\
\hline \multirow{3}{*}{ Parental Involvement } & PI1 & 4.316 & 0.698 \\
\hline & PI2 & 4.423 & 0.732 \\
\hline & PI3 & 3.950 & 0.961 \\
\hline \multirow{3}{*}{ Digital Contents } & DC1 & 3.760 & 0.972 \\
\hline & DC2 & 3.836 & 0.946 \\
\hline & DC3 & 3.812 & 0.915 \\
\hline \multirow{3}{*}{ SexEd Knowledge } & SK1 & 3.770 & 0.996 \\
\hline & SK2 & 3.937 & 0.957 \\
\hline & SK3 & 3.911 & 0.924 \\
\hline \multirow{3}{*}{ SexEd Openness } & OP1 & 4.065 & 0.907 \\
\hline & OP2 & 4.120 & 0.837 \\
\hline & OP3 & 4.010 & 0.911 \\
\hline \multirow{3}{*}{ SexEd Teacher Readiness } & TR1 & 4.316 & 0.738 \\
\hline & TR2 & 4.110 & 0.860 \\
\hline & TR3 & 3.875 & 0.964 \\
\hline
\end{tabular}

Three indicators were used to evaluate the internal consistency and convergent validity for each component (see Table 4). Cronbach's alpha is denoted by Alpha. It is a measure of the internal consistency of an instrument or scale developed by Cronbach (1951); it ranges between 0 and 1. In terms of internal consistency, all of the items in a test measure the same concept, so it is related to how closely they relate to each other. Different studies recommend a range of acceptable values for alpha, from 0.70 to 0.95 (Tavakol \& Dennick, 2011). The measurements internal consistency values in this study are mostly within the range of recommended values, except facilitating conditions (Alpha $=0.68$ ), but it is close to 0.7 , indicating an acceptable value. Rather than relying solely on Cronbach's alpha to evaluate 
each construct's dependability, Dillon-rho Goldstein's was presented to verify each construct's internal consistency and dependability criteria (Hwang \& Takane, 2014). All results were more than 0.7, above the required reliability estimate (Hwang \& Takane, 2014). Average Variance Extracted (AVE) was examined to determine whether it was convergent. AVE's values were greater than 0.5 , suggesting convergent validity (Hwang \& Takane, 2014).

Table 4. Internal consistency and convergent validity.

\begin{tabular}{|l|c|c|c|}
\hline \multicolumn{1}{|c|}{ Construct } & Alpha & Dillon-Goldstein's Rho & AVE \\
\hline Performance Expectancy & 0.783 & 0.873 & 0.835 \\
\hline Effort Expectancy & 0.806 & 0.873 & 0.795 \\
\hline Educational Policy & 0.888 & 0.931 & 0.904 \\
\hline Facilitating Conditions & 0.680 & 0.807 & 0.720 \\
\hline Parental Involvement & 0.705 & 0.836 & 0.794 \\
\hline Digital Contents & 0.866 & 0.918 & 0.888 \\
\hline SexEd Knowledge & 0.833 & 0.900 & 0.866 \\
\hline SexEd Openness & 0.868 & 0.919 & 0.889 \\
\hline SexEd Teacher Readiness & 0.714 & 0.840 & 0.799 \\
\hline
\end{tabular}

Table 5 shows standard errors (SEs) and 95\% bootstrap percentile confidence intervals (CIs) calculated from item loading estimates simulations, as well as respective lower and upper bounds. 100 bootstrap samples were used to determine the confidence intervals (CIs). If a 95 percent confidence interval did not include zero, the parameter estimates were considered significant at the 0.05 level. All loading estimates were statistically significant, showing that all items were reliable predictors of constructs.

Table 5. Estimates of loadings.

\begin{tabular}{|l|l|l|l|l|}
\hline & Estimate & Standard Errors & 95\%CI_LB & 95\%CI_UB \\
\hline \multicolumn{5}{|l|}{ SexEd Knowledge } \\
\hline SK1 & 0.881 & 0.019 & 0.837 & 0.906 \\
\hline SK2 & 0.895 & 0.013 & 0.870 & 0.917 \\
\hline SK3 & 0.820 & 0.024 & 0.763 & 0.865 \\
\hline Digital Contents \\
\hline DC1 & 0.899 & 0.012 & 0.875 & 0.922 \\
\hline DC2 & 0.861 & 0.021 & 0.822 & 0.897 \\
\hline DC3 & 0.905 & 0.017 & 0.869 & 0.931 \\
\hline SexEd Openness & \\
\hline OP1 & 0.910 & 0.015 & 0.872 & 0.933 \\
\hline OP2 & 0.864 & 0.022 & 0.815 & 0.906 \\
\hline OP3 & 0.894 & 0.015 & 0.863 & 0.925 \\
\hline Facilitating Conditions & \\
\hline FC1 & 0.803 & 0.026 & 0.747 & 0.849 \\
\hline FC2 & 0.773 & 0.027 & 0.719 & 0.826 \\
\hline FC3 & 0.491 & 0.075 & 0.334 & 0.611 \\
\hline FC4 & 0.770 & 0.033 & 0.701 & 0.838 \\
\hline
\end{tabular}




\begin{tabular}{|l|l|l|l|l|}
\hline Effort Expectancy \\
\hline EE1 & 0.797 & 0.024 & 0.740 & 0.842 \\
\hline EE2 & 0.753 & 0.045 & 0.645 & 0.826 \\
\hline EE3 & 0.835 & 0.020 & 0.795 & 0.873 \\
\hline EE4 & 0.792 & 0.030 & 0.731 & 0.850 \\
\hline Performance Expectancy \\
\hline PE1 & 0.828 & 0.020 & 0.787 & 0.860 \\
\hline PE2 & 0.833 & 0.019 & 0.790 & 0.874 \\
\hline PE3 & 0.843 & 0.021 & 0.795 & 0.879 \\
\hline Parental Involvement \\
\hline PI1 & 0.803 & 0.029 & 0.742 & 0.852 \\
\hline PI2 & 0.847 & 0.024 & 0.795 & 0.896 \\
\hline PI3 & 0.728 & 0.028 & 0.664 & 0.772 \\
\hline Educational Policy & \multicolumn{5}{l|}{} \\
\hline EP1 & 0.914 & 0.011 & 0.890 & 0.934 \\
\hline EP2 & 0.929 & 0.009 & 0.907 & 0.943 \\
\hline EP3 & 0.869 & 0.017 & 0.833 & 0.898 \\
\hline Teacher Readiness & \\
\hline TR1 & 0.836 & 0.023 & 0.784 & 0.879 \\
\hline TR2 & 0.838 & 0.022 & 0.777 & 0.879 \\
\hline TR3 & 0.716 & 0.040 & 0.639 & 0.787 \\
\hline
\end{tabular}

Table 6 presented that GSCA gave FIT $=0.551(\mathrm{SE}=0.0113,95 \%$ CIs $=0.5425-$ $0.5851), \mathrm{AFIT}=0.548(\mathrm{SE}=0.0116,95 \% \mathrm{CIs}=0.5293-0.5923), \mathrm{GFI}=0.973(\mathrm{SE}=$ $0.0062,95 \% \mathrm{CIs}=0.962-0.9878)$, and SRMR $=0.071(\mathrm{SE}=0.0145,95 \% \mathrm{CIs}=0.069$ - 0.0782). The variation of the data explained by a particular model specification was examined by both FIT and Adjusted FIT (AFIT). FIT and Adjusted FIT (AFIT) were used to estimate how much variation in the data can be explained by specific model specifications. If the number is higher, more variance is explained by linear regression. Thus, the model accounted for a total variance of $55.1 \%$ and $54.8 \%$, respectively. FIT and AFIT were significantly different from zero (no inclusion of zero value in CIs range). Additionally, goodness-of-fit indexes (GFIs) and standardized root mean square residuals (SRMRs) are indicators of the closeness between sample covariance and covariance as additional measures of the fit of an overall model. Based on a recent study, the following cut-off criteria for GFI and SRMR have been suggested in GSCA (Cho et al., 2020); For sample sizes > 100, a GFI $\geq .93$ or an SRMR $\geq .08$ indicates a good fit. Results from Table 6 indicated that GFI and SRMR satisfied the recommended value.

Table 6. Model FIT.

\begin{tabular}{|l|l|l|l|l|}
\hline & Estimate & SE & 95\%CI_LB & 95\%CI_UB \\
\hline FIT & 0.551 & 0.0113 & 0.5425 & 0.5851 \\
\hline Adjusted FIT (AFIT) & 0.548 & 0.0116 & 0.5293 & 0.5923 \\
\hline GFI & 0.973 & 0.0062 & 0.962 & 0.9878 \\
\hline SRMR & 0.071 & 0.0145 & 0.069 & 0.0782 \\
\hline
\end{tabular}

Therpath coefficients areshown in Table 7aswell as their 95\% confidence intervals ankestandarfwernos Timathe, 2 stuy).ctural model. The results indicated that the 
influence of facilitating condition on SexEd teacher readiness was statistically significant and positive $\left(\mathrm{H} 1=0.14^{*}, \mathrm{SE}=0.06,95 \% \mathrm{CIs}=0.9768-0.9977\right)$. Teacher Readiness was statistically significant and positively influenced by Educational Policy $\left(\mathrm{H} 4=0.306^{*}, \mathrm{SE}=0.091,95 \% \mathrm{CIs}=0.123-0.468\right)$. Parental Involvement had a statistically significant and positive influence on Teacher Readiness $\left(\mathrm{H} 5=0.371^{*}\right.$, $\mathrm{SE}=0.062,95 \% \mathrm{CI}=0.23-0.473)$. In addition, Digital Contents positively influenced Performance Expectancy $\left(\mathrm{H} 6=0.26^{*}, \mathrm{SE}=0.061,95 \% \mathrm{CIs}=0.16-\right.$ 0.383). Digital Contents positively predicted Effort Expectancy $\left(\mathrm{H} 7=0.151^{*}, \mathrm{SE}=\right.$ $0.073,95 \%$ CIs $=0.031-0.346)$. Furthermore, SexEd Knowledge had a positive influence on Effort Expectancy $\left(\mathrm{H} 8=0.445^{*}, \mathrm{SE}=0.077,95 \%\right.$ CIs $\left.=0.251-0.568\right)$. Finally, Performance Expectancy was statistically significant and positively influenced by SexEd Openness on delivering SexEd in primary schools $(\mathrm{H} 9=$ $\left.0.434^{*}, \mathrm{SE}=0.063,95 \% \mathrm{CIs}=0.292-0.525\right)$.

The hypotheses H2 (Effort Expectancy (H2) $\rightarrow$ Teacher Readiness), H3 (Performance Expectancy (H3) $\rightarrow$ Teacher Readiness) were not supported as zero values were found in the CIs.

Table 7. Estimates of path coefficients.

\begin{tabular}{|l|c|c|c|c|}
\hline & Estimates & $\begin{array}{r}\text { Std } \\
\text { Error }\end{array}$ & $\begin{array}{r}\text { 95\% } \\
\text { CI_LB }\end{array}$ & $\begin{array}{r}\text { 95\% } \\
\text { CI_UB }\end{array}$ \\
\hline $\begin{array}{l}\text { Facilitating Conditions (H1) } \rightarrow \text { Teacher } \\
\text { Readiness }\end{array}$ & $0.14^{*}$ & 0.06 & 0.025 & 0.251 \\
\hline $\begin{array}{l}\text { Effort Expectancy (H2) } \rightarrow \text { Teacher } \\
\text { Readiness }\end{array}$ & 0.08 & 0.066 & -0.044 & 0.201 \\
\hline $\begin{array}{l}\text { Performance Expectancy (H3) } \rightarrow \text { Teacher } \\
\text { Readiness }\end{array}$ & -0.129 & 0.06 & -0.212 & 0.005 \\
\hline $\begin{array}{l}\text { Educational Policy (H4) } \rightarrow \text { Teacher } \\
\text { Readiness }\end{array}$ & $0.306^{*}$ & 0.091 & 0.123 & 0.468 \\
\hline $\begin{array}{l}\text { Parental Involvement (H5) } \rightarrow \text { Teacher } \\
\text { Readiness }\end{array}$ & $0.371^{*}$ & 0.062 & 0.23 & 0.473 \\
\hline $\begin{array}{l}\text { Digital Contents (H6) } \rightarrow \text { Performance } \\
\text { Expectancy }\end{array}$ & $0.26^{*}$ & 0.061 & 0.16 & 0.383 \\
\hline Digital Contents (H7) $\rightarrow$ Effort Expectancy & $0.151^{*}$ & 0.073 & 0.031 & 0.346 \\
\hline $\begin{array}{l}\text { SexEd Knowledge (H8) } \rightarrow \text { Effort } \\
\text { Expectancy }\end{array}$ & $0.445^{*}$ & 0.077 & 0.251 & 0.568 \\
\hline $\begin{array}{l}\text { SexEd Openness (H9) } \rightarrow \text { Performance } \\
\text { Expectancy }\end{array}$ & $0.434^{*}$ & 0.063 & 0.292 & 0.525 \\
\hline
\end{tabular}

* Statistically significant at 0.05 level.

\section{Discussion}

In Holsapple and Lee-Post (2006)'s research, teachers who score 4 on a Likert-type scale are considered e-ready. The primary teachers' responses had a mean of 4.1, meaning that cohorts were moderately ready or slightly over the teacher readiness threshold. The current finding was in line with (Cabreros, 2012) where the author reported that teachers acknowledged a modest readiness to teach kids about sex education subjects. Additionally, Effort Expectancy (mean $=4.063)$, Parental 
Involvement $($ mean $=4.230)$, and SexEd Openness $($ mean $=4.065)$ all have comparable scores and interpretations when using the same threshold. On the other hand, Performance Expectancy $($ mean $=3.978)$, Educational Policy $($ mean $=$ 3.866), Facilitating Conditions (mean $=3.740)$, Digital Contents $($ mean $=3.803)$, SexEd knowledge $($ mean $=3.872$ ) produced means slightly below the threshold level. In contrast to what one might expect that government, schools, and thirdparty organizations would provide strong support for teachers/students for teaching and learning at home to sustain education in the context of the Covid-19 pandemic, the mean of facilitating conditions was lower than the expected threshold. One plausible explanation for this shortage may be attributed to the fact that network conditions, infrastructure, and supporting technological devices were not kept up with the suddenly increased demand, especially in developing countries (Fauzi \& Khusuma, 2020; Wu, 2021). It was not surprising that digital contents expectancy for SexEd was lower than the threshold value. Traditionally, digital teaching has served only as a complement in elementary and secondary schools. As a result, elementary school teachers have limited time to produce engaging digital material or even switch to an online environment (Fauzi \& Khusuma, 2020; Lestari \& Gunawan, 2020). This is also true for less popular subjects, such as SexEd. In terms of educational policy with guidelines, our finding was aligned with existing studies (Almazova et al., 2020; Andarwulan et al., 2021; Fauzi \& Khusuma, 2020) where teachers faced difficulties in transitioning to the virtual space, thus the is a need to provide clear guidance for teachers, especially in the elementary sector. In terms of SexEd knowledge, the survey suggested that knowledge confidence in SexEd was slightly below the threshold, and our findings were consistent with (Javadnoori et al., 2016; Martin et al., 2020), where the results were reported that teachers lacked comprehensive understanding and awareness on child sex-related issues.

\subsection{Theoretical implication}

One of the most noteworthy findings was the amount of variation that explained the hypothesized model (55.1\%). The current study's findings validated the majority of the predicted correlations among the factors in the proposed model. The notable exception is that Effort Expectancy was not found to predict Teacher Readiness, and Performance Expectancy was not found to influence Teacher Readiness for delivering SexEd via virtual space. One probable reason for these non-significant findings is that, as described in the previous section, not all teachers received the same educational training/guidelines, especially for primary teachers. Thus, the level of expectancy for these factors varied. As such, in the subsequent studies, there is a need to investigate these two factors in more detail, considering a specific context.

Nevertheless, findings of this study contribute to the body of knowledge in two folds: (1) it empirically verified the effects on relationships embedded in existing theories, thus it can be employed as a reference in a similar setting, and (2) for hypotheses which were not supported, more studies are called to investigate these non-significant behaviors. 


\subsection{Practical implication}

The study's context stems from the fact that primary teachers and children were forced to study from home. SexEd teachers are undoubtedly encountered many challenges for their readiness. As a result, there is a strong need to study or investigate factors that influence their behaviors.

In terms of teacher readiness, the findings from the proposed model revealed that Facilitating Conditions, Educational Policy, and Parental Involvement all had a relationship with Teacher Readiness. Policymakers should focus on training primary teachers to use digital devices/apps more efficiently, the clearer guidance the better teacher readiness. Since the availability of devices/tools/apps is a reliable predictor in this context, governments and institutions should constantly improve infrastructure, provide teachers with modern devices, and build robust tools/apps. In terms of Parental Involvement, teachers and parents should cooperate in providing SexEd to children, especially when the class is running. This is vital not only in SexEd but also in other subjects or classes since children are easily distracted, unfocused, or exhausted. In terms of SexEd digital content, it is challenging for teachers to create engaging materials but use existing videos or slides. As a result, professionals are brought in to help with this procedure. To attract researchers/developers from different areas, the government and colleges might fund the content creation via institutional or national grants. SexEd openness is another important component supported by the research model; thus, teachers should participate in public speaking or social media to build their confidence and readiness to share and educate people about the relevance of SexEd in childhood. As for the SexEd knowledge, teachers should keep learning progressively to broaden their knowledge. In addition to self-learning, teacher competency standards for SexEd should be revised to accommodate the social changes (Nhung Nguyen Thi Phuong et al., 2021) and policymakers can utilize these findings to justify training programs.

\subsection{Limitations}

Even though the conclusions are grounded on the contributions, they will necessarily be limited by a variety of restrictions. These constraints, when combined with unexpected discoveries, point to a viable future study framework. First of all, non-probability sampling was used for this study to ensure that all respondents are SexEd primary teachers. The study's sampling method, although widely accepted in the literature, limits the generalizability of findings beyond those in the study. Second, because this study examined teacher readiness during a short period, particularly considering Covid-19, the study's conclusions must be revisited after the outbreak. Furthermore, because the current study's theoretical framework was only based on variables obtained from selected factors, other mediators and moderators not included in the proposed model were not assessed.

\section{Conclusion}

This study examined the factors influencing primary school teachers' readiness to provide children with SexEd in terms of digital contents, sexual knowledge, openness, facilitating conditions, effort expectancy, performance expectancy, educational policy, and parental engagement. The study`s findings, based on data 
from 383 individuals, verified many of the expected correlations between the factors in the proposed model, that is, Facilitating Conditions, Educational Policy, and Parental Involvement all had a relationship with Teacher Readiness. Digital Contents positively influenced Performance Expectancy and Effort Expectancy. SexEd Knowledge had a statistically significant and positive influence on Effort Expectancy. Finally, SexEd Openness had a statistically significant and positive influence on Performance Expectancy on delivering SexEd in primary schools. The significant exceptions were that Effort Expectancy was not found to predict Teacher Readiness, and Performance Expectancy was not found to influence Teacher Readiness for delivering SexEd in an online environment. The reasons for these non-significant correlations were briefly discussed and more studies on this topic are called to investigate these unexpected outcomes in more detail.

\section{Funding}

This work was supported by a grant from the Ministry of Education and Training, Vietnam B2020-TDV-06.

\section{References}

Adov, L., Must, O., \& Pedaste, M. (2017). Attitudes towards Mobile devices in Estonian basic education: Using the framework of the UTAUT model. International Conference on Learning and Collaboration Technologies,

Alea, L. A., Fabrea, M. F., Roldan, R. D. A., \& Farooqi, A. Z. (2020). Teachers' Covid-19 awareness, distance learning education experiences and perceptions towards institutional readiness and challenges. International Journal of Learning, Teaching and Educational Research, 19(6), 127-144. https://doi.org/10.26803/ijlter.19.6.8

Alghamdi, A. K. H., \& Al-Ghamdi, N. A. (2021). Elementary Teachers' Thoughts about Distance Education and Learning 21st-Century Skills during COVID Pandemic. International Journal of Learning, Teaching and Educational Research, 20(3). https://doi.org/10.26803/ijlter.20.3.3

Almazova, N., Krylova, E., Rubtsova, A., \& Odinokaya, M. (2020). Challenges and opportunities for Russian higher education amid COVID-19: Teachers'

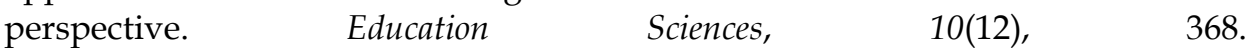
https://doi.org/10.3390/educsci10120368

Andarwulan, T., Fajri, T. A. A., \& Damayanti, G. (2021). Elementary Teachers' Readiness toward the Online Learning Policy in the New Normal Era during COVID-19. International Journal of Instruction, 14(3), 771-786. https:// doi.org/10.29333/iji.2021.14345a

Aventin, Á., Gough, A., McShane, T., Gillespie, K., O’Hare, L., Young, H., Lewis, R., Warren, E., Buckley, K., \& Lohan, M. (2020). Engaging parents in digital sexual and reproductive health education: evidence from the JACK trial. Reproductive Health, 17(1), 1-18. https:// doi.org/10.1186/s12978-020-00975-y

Azizi, S. M., Roozbahani, N., \& Khatony, A. (2020). Factors affecting the acceptance of blended learning in medical education: application of UTAUT2 model. BMC medical education, 20(1), 1-9. https:// doi.org/10.1186/s12909-020-02302-2

Bartau-Rojas, I., Aierbe-Barandiaran, A., \& Oregui-González, E. (2018). Parental mediation of the Internet use of Primary students: beliefs, strategies and difficulties. Comunicar. Media Education Research Journal, 26(1). https:/ / doi.org/10.3916/C542018-07

Bautista Jr, A., Bleza, D., Buhain, C., \& Balibrea, D. (2021). School Support Received and the Challenges Encountered in Distance Learning Education by Filipino Teachers 
during the Covid-19 Pandemic. International Journal of Learning, Teaching and Educational Research. https://doi.org/10.26803/ijlter.20.6.19

Berglas, N. F., Jerman, P., Rohrbach, L. A., Angulo-Olaiz, F., Chou, C.-P., \& Constantine, N. A. (2016). An implementation and outcome evaluation of a multicomponent sexuality education programme for high school students. Sex education, 16(5), 549567. https://doi.org/10.1080/14681811.2015.1133408

Booth-Butterfield, M., \& Sidelinger, R. (1998). The influence of family communication on the college-aged child: Openness, attitudes and actions about sex and alcohol. Communication Quarterly, 46(3), 295-308. https://doi.org/10.1080/01463379809370103

Borotis, S., \& Poulymenakou, A. (2004). E-learning readiness components: Key issues to consider before adopting e-learning interventions. [https://www.learntechlib.org/primary/p/11555/]. E-Learn: World Conference on E-Learning in Corporate, Government, Healthcare, and Higher Education,

Cabreros, M. A. (2012). Handa na ba ako?: parents' receptiveness and teachers' readiness of sex education in grade school. http://cas.upm.edu.ph:8080/xmlui/handle/123456789/147

Cacciatore, R., Korteniemi-Poikela, E., \& Kaltiala, R. (2019). The steps of sexuality -a developmental, emotion-focused, child-centered model of sexual development and sexuality education from birth to adulthood. International Journal of Sexual Health, 31(3), 319-338. https:// doi.org/10.1080/19317611.2019.1645783

Cho, G., Hwang, H., Sarstedt, M., \& Ringle, C. M. (2020). Cutoff criteria for overall model fit indexes in generalized structured component analysis. Journal of Marketing Analytics, 8(4), 189-202. https:// doi.org/10.1057/s41270-020-00089-1

Choi, Y. H. (2013). A study of experience of sex education, awareness of sexual abuse, sex knowledge, and sexual consciousness of children. The Korean Journal of Community Living Science, 24(3), 355-368. https:// doi.org/10.7856/kjcls.2013.24.3.355

Churiyah, M., Sholikhan, S., Filianti, F., \& Sakdiyyah, D. A. (2020). Indonesia education readiness conducting distance learning in Covid-19 pandemic situation. International Journal of Multicultural and Multireligious Understanding, 7(6), 491-507. https://doi.org/10.18415/ijmmu.v7i6.1833

Cronbach, L. J. (1951). Coefficient alpha and the internal structure of tests. Psychometrika, 16(3), 297-334. https://doi.org/10.1007/BF02310555

Desforges, C., \& Abouchaar, A. (2003). The impact of parental involvement, parental support and family education on pupil achievement and adjustment: A literature review (Vol. 433). DfES London. http://dera.ioe.ac.uk/id/eprint/6305

Dorsah, P. (2021). Pre-Service Teachers' Readiness for Emergency Remote Learning in the Wake of COVID-19. European Journal of STEM Education, 6(1), 1. https://doi.org/10.20897/ejsteme/9557

Espinosa, A. L. H., \& Barraza, A. R. (2021). Elementary School Teachers and Sex Education in Mexico: The Case of Veracruz. International Electronic Journal of Elementary Education, 13(5), 589-598. https:// doi.org/10.26822/iejee.2021.214

Fauzi, I., \& Khusuma, I. H. S. (2020). Teachers' elementary school in online learning of COVID-19 pandemic conditions. Jurnal Iqra': Kajian Ilmu Pendidikan, 5(1), 58-70. https://doi.org/10.25217/ji.v5i1.914

Ferri, F., Grifoni, P., \& Guzzo, T. (2020). Online learning and emergency remote teaching: Opportunities and challenges in emergency situations. Societies, 10(4), 86. https://doi.org/10.3390/soc10040086

Fiangga, S., Palupi, E. L. W., Hidayat, D., Prihartiwi, N. R., \& Siswono, T. Y. E. (2021). Development of digital learning resources for realistic mathematics education in 
supporting virtual learning during covid-19. Journal of Physics: Conference Series.

Funa, A. A., \& Talaue, F. T. (2021). Constructivist Learning Amid the COVID-19 Pandemic: Investigating Students' Perceptions of Biology Self-Learning Modules. Online Submission, 20(3), 250-264. https://doi.org/10.26803/ijlter.20.3.15

Gallegos, J. C. P., de la Torre, B. A. T., \& Sprock, A. S. (2020). Distance Education. An Emerging Strategy for Education in the pandemic COVID19. [10.1109/LACLO50806.2020.9381137]. 2020 XV Conferencia Latinoamericana de Tecnologias de Aprendizaje (LACLO),

Gocotano, T. E., Jerodiaz, M. A. L., Banggay, J. C. P., Nasibog, H. B. R., \& Go, M. B. (2021). Higher Education Students' Challenges on Flexible Online Learning Implementation in the Rural Areas: A Philippine Case. International Journal of Learning, Teaching and Educational Research, 20(7). https://doi.org/10.26803/ijlter.20.7.15

Goldfarb, E. S., \& Lieberman, L. D. (2021). Three decades of research: The case for comprehensive sex education. Journal of Adolescent Health, 68(1), 13-27. https://doi.org/10.1016/j.jadohealth.2020.07.036

Hamilton-Giachritsis, C., Hanson, E., Whittle, H., Alves-Costa, F., Pintos, A., Metcalf, T., \& Beech, A. (2021). Technology assisted child sexual abuse: professionals' perceptions of risk and impact on children and young people. Child abuse $\mathcal{E}$ neglect, 119, 104651. https://doi.org/10.1016/j.chiabu.2020.104651

Holsapple, C. W., \& Lee-Post, A. (2006). Defining, assessing, and promoting e-learning success: An information systems perspective. Decision sciences journal of innovative education, 4(1), 67-85. https:// doi.org/10.1111/j.1540-4609.2006.00102.x

Hu, S., Laxman, K., \& Lee, K. (2020). Exploring factors affecting academics' adoption of emerging mobile technologies-an extended UTAUT perspective. Education and Information Technologies, 25(5), 4615-4635. https://doi.org/10.1007/s10639-02010171-x

Hung, M.-L. (2016). Teacher readiness for online learning: Scale development and teacher perceptions. Computers \& Education, 94, 120-133. https://doi.org/10.1016/j.compedu.2015.11.012

Hwang, H., Cho, G., \& Choo, H. (2021). GSCA Pro 1.0 User's Manual. https://www.gscapro.com/

Hwang, H., \& Takane, Y. (2014). Generalized structured component analysis: A componentbased approach to structural equation modeling. CRC Press. https://doi.org/10.1201/b17872

Iivari, N., Sharma, S., \& Ventä-Olkkonen, L. (2020). Digital transformation of everyday life-How COVID-19 pandemic transformed the basic education of the young generation and why information management research should care? International Journal of Information Management, 55, 102183. https://doi.org/10.1016/j.ijinfomgt.2020.102183

Initiative, F. o. S. E. (2020). National sex education standards: Core content and skills, K12. Future of Sex Education Initiative. https://advocatesforyouth.org/wpcontent/uploads/2020/03/NSES-2020-web.pdf

Javadnoori, M., Zangeneh, S., Tadayon, M., \& Akhoond, M. (2016). Competence of healthcare Workers in Sexual Health Education for female adolescents at schools. Journal of Midwifery and Reproductive Health, 4(2), 605-612. https://doi.org/10.22038/jmrh.2016.6627

Jin, X. (2021). The characteristics and relationship of parental sexual knowledge and sex education attitude to young children. Creative Education, 12(9), 2002-2010. https://doi.org/10.4236/ce.2021.129153 
Jørgensen, C. R., Weckesser, A., Turner, J., \& Wade, A. (2019). Young people's views on sexting education and support needs: Findings and recommendations from a UK$\begin{array}{llll}\text { based study. Sex education, 19(1), 25-40. } & \text {. }\end{array}$ https://doi.org/10.1080/14681811.2018.1475283

Kim, H., Park, K.-H., \& Park, S. (2021). Gender differences in sexual behaviors and their relevance to mental health among high school students with sexual experience in South Korea. International Journal of Environmental Research and Public Health, 18(21), 11295. https://doi.org/10.3390/ijerph182111295

Kirkman, M., Rosenthal, D. A., \& Shirley Feldman, S. (2005). Being open with your mouth shut: The meaning of 'openness' in family communication about sexuality. Sex education, 5(1), 49-66. https://doi.org/10.1080/1468181042000301885

Kock, N., \& Hadaya, P. (2018). Minimum sample size estimation in PLS-SEM: The inverse square root and gamma-exponential methods. Information Systems Journal, 28(1), 227-261. https://doi.org/10.1111/isj.12131

Lameiras-Fernández, M., Martínez-Román, R., Carrera-Fernández, M. V., \& RodríguezCastro, Y. (2021). Sex education in the spotlight: what is working? Systematic review. International Journal of Environmental Research and Public Health, 18(5), 2555. https://doi.org/10.3390/ijerph18052555

Lestari, P. A. S., \& Gunawan, G. (2020). The impact of Covid-19 pandemic on learning implementation of primary and secondary school levels. Indonesian Journal of Elementary and Childhood Education, 1(2), 58-63.

Leung, H., Shek, D. T., Leung, E., \& Shek, E. Y. (2019). Development of contextuallyrelevant sexuality education: Lessons from a comprehensive review of adolescent sexuality education across cultures. International Journal of Environmental Research and Public Health, 16(4), 621. https://doi.org/10.3390/ijerph16040621

Martin, J., Riazi, H., Firoozi, A., \& Nasiri, M. (2020). A sex education program for teachers of preschool children: a quasi-experimental study in Iran. BMC public health, 20, 19. https://doi.org/10.1186/s12889-020-08826-y

Mittal, A., Mantri, A., Tandon, U., \& Dwivedi, Y. K. (2021). A unified perspective on the adoption of online teaching in higher education during the COVID-19 pandemic. Information Discovery and Delivery. https:/ / doi.org/10.1108/IDD-09-2020-0114

Nhung Nguyen Thi Phuong, An Chu Thi Thuy, Hien Nguyen Ngoc, Ly Tran Hang, \& Xuan, S. P. (2021). A Revision of Sex Competency Framework toward Digital Transformation and Covid-19 Pandemic. International Journal of Innovation, Creativity and Change, 15(8), 389-409.

Omar, M., Ismail, S., \& Kasim, A. (2019). The Influence of Mobile Technology Adoption among Secondary School Teachers using the UTAUT 2 Model. International Journal of Recent Technology and Engineering (IJRTE), 8(4). https://doi.org/10.35940/ijrte.D8204.118419

Patra, S. K., Sundaray, B. K., \& Mahapatra, D. M. (2021). Are university teachers ready to use and adopt e-learning system? An empirical substantiation during COVID-19 pandemic. Quality Assurance in Education. https:/ / doi.org/10.1108/QAE-12-20200146

Pellejero Goni, L., \& Torres Iglesias, B. (2011). Sex education: Sex and gender in Primary School textbooks. Revista de Educación(354), 399-427.

Plaza-del-Pino, F. J., Soliani, I., Fernández-Sola, C., Molina-García, J. J., Ventura-Miranda, M. I., Pomares-Callejón, M. Á., López-Entrambasaguas, O. M., \& Ruiz-Fernández, M. D. (2021). Primary school teachers' perspective of sexual education in Spain. A $\begin{array}{llll}\text { qualitative study. } & \text { Healthcare, } & 9(3), & \end{array}$ https://doi.org/10.3390/healthcare9030287 
Pokhrel, S., \& Chhetri, R. (2021). A literature review on impact of COVID-19 pandemic on teaching and learning. Higher Education for the Future, 8(1), 133-141. https:// doi.org/10.1177/2347631120983481

Russell, D., Higgins, D., \& Posso, A. (2020). Preventing child sexual abuse: A systematic review of interventions and their efficacy in developing countries. Child abuse $\mathcal{E}$ neglect, 102, 104395. https:/ / doi.org/10.1016/j.chiabu.2020.104395

Sailer, M., Schultz-Pernice, F., \& Fischer, F. (2021). Contextual facilitators for learning activities involving technology in higher education: The Cb-model. Computers in Human Behavior, 121, 106794. https:/ / doi.org/10.1016/j.chb.2021.106794

Schneider, M., \& Hirsch, J. S. (2020). Comprehensive sexuality education as a primary prevention strategy for sexual violence perpetration. Trauma, Violence, $\mathcal{E}$ Abuse, 21(3), 439-455. https://doi.org/10.1177/1524838018772855

Shareefa, M., Muneez, M., Hammad, A., \& Shihamaa, M. (2021). Enhancing Virtual Learning during the Crisis of COVID-19 Lockdown-A Case Study of a Higher Education Institution in Maldives. International Journal of Learning, Teaching and Educational Research, 20(11). https:/ / doi.org/10.26803/ijlter.20.11.26

Shin, H., Lee, J. M., \& Min, J. Y. (2019). Sexual knowledge, sexual attitudes, and perceptions and actualities of sex education among elementary school parents. Child Health Nursing Research, 25(3), 312-323. https://doi.org/10.4094/chnr.2019.25.3.312

Soper, D. (2016). Calculator: a-priori sample size for structural equation models. https://www.danielsoper.com/statcalc/calculator.aspx?id=89

Steiner, G. (2012). Educational learning theory. Instructional design: International perspectives, 1, 79-112. https://doi.org/10.1016/B978-0-08-097086-8.92150-0

Stevens, M., \& Borup, J. (2015). Parental engagement in online learning environments: A review of the literature. Exploring Pedagogies for Diverse Learners Online. https://doi.org/10.1108/S1479-368720150000027005

Stratton, S. J. (2021). Population research: convenience sampling strategies. Prehospital and disaster Medicine, 36(4), 373-374. https://doi.org/10.1017/S1049023X21000649

Tadesse, S., \& Muluye, W. (2020). The impact of COVID-19 pandemic on education system in developing countries: a review. Open Journal of Social Sciences, 8(10), 159-170. https://doi.org/10.4236/jss.2020.810011

Tavakol, M., \& Dennick, R. (2011). Making sense of Cronbach's alpha. International journal of medical education, 2, 53. https://doi.org/0.5116/ijme.4dfb.8dfd

Venkatesh, V., Morris, M. G., Davis, G. B., \& Davis, F. D. (2003). User acceptance of information technology: Toward a unified view. MIS quarterly, 425-478. https://doi.org/10.2307/30036540

Voyiatzaki, C., Venetikou, M. S., Papageorgiou, E., Anthouli-Anagnostopoulou, F., Simitzis, P., Chaniotis, D. I., \& Adamopoulou, M. (2021). Awareness, Knowledge and Risky Behaviors of Sexually Transmitted Diseases among Young People in Greece. International Journal of Environmental Research and Public Health, 18(19), 10022. https:// doi.org/10.3390/ijerph181910022

Wang, H., \& Hall, N. C. (2018). A systematic review of teachers' causal attributions: Prevalence, correlates, and consequences. Frontiers in psychology, 9, 2305. https://doi.org/10.3389/fpsyg.2018.02305

Warner, D., Christie, G., \& Choy, S. (1998). Readiness of VET clients for flexible delivery including on-line learning. Brisbane: Australian National Training Authority. http://hdl.voced.edu.au/10707/33256

Warzecha, D., Szymusik, I., Pietrzak, B., Kosinska-Kaczynska, K., Sierdzinski, J., SochackiWojcicka, N., \& Wielgos, M. (2019). Sex education in Poland-a cross-sectional study evaluating over twenty thousand polish women's knowledge of 
reproductive health issues and contraceptive methods. BMC public health, 19(1), 18. https://doi.org/10.1186/s12889-019-7046-0

Wenceslao, P., \& Felisa, G. (2021). Challenges to Online Engineering Education during the Covid-19 Pandemic in Eastern Visayas, Philippines. International Journal of Learning, Teaching and Educational Research, 20(3). https://doi.org/10.26803/ijlter.20.3.6

Westwood, J., \& Mullan, B. (2007). Knowledge and attitudes of secondary school teachers regarding sexual health education in England. Sex education, 7(2), 143-159. https://doi.org/10.1080/14681810701264490

$\mathrm{Wu}$, S.-Y. (2021). How teachers conduct online teaching during the COVID-19 pandemic: A case study of Taiwan. Frontiers in Education, 6(675434), 11-11. https://doi.org/10.3389/feduc.2021.675434

Zakharov, K., Komarova, A., Baranova, T., \& Gulk, E. (2021). Information literacy and digital competence of teachers in the age of digital transformation. E3S Web of Conferences,

Zou, C., Li, P., \& Jin, L. (2021). Online college English education in Wuhan against the COVID-19 pandemic: Student and teacher readiness, challenges and implications. PloS one, 16(10), e0258137. https://doi.org/10.1371/journal.pone.0258137 